\title{
PENGARUH MODEL PEMBELAJARAN EXAMPLE NON EXAMPLE MODIFIKASI METODE TUTOR SEBAYA TERHADAP KEMAMPUAN PENALARAN MATEMATIS DAN KONEKSI MATEMATIS PESERTA DIDIK PADA MATERI BANGUN RUANG
}

\author{
(THE INFLUENCE OF THE EXAMPLE NON EXAMPLE LEARNING \\ MODEL MODIFICATION OF THE PEER TUTOR METHOD ON THE \\ MATHEMATICAL REASONING ABILITIES AND MATHEMATICAL \\ CONNECTION OF STUDENTS IN THE BUILDING MATERIAL)
}

\section{Dewi Ayu Ajeng Ning Tias ${ }^{1}$, Bambang Sri Anggoro ${ }^{1}$, Novian Riskiana Dewi ${ }^{1}$ \\ ${ }^{1}$ Universitas Islam Negeri Raden Intan Lampung, dewiayuajeng10@ gmail.com}

\begin{abstract}
Abstrak
Penelitian ini bertujuan untuk mengetahui pengaruh model pembelajaran Example Non Example modifikasi metode tutor sebaya terhadap kemampuan penalaran matematis dan koneksi matematis peserta didik pada materi bangun ruang. Penelitian ini merupakan jenis penelitian Quasi Experimental Design dan populasinya yaitu peserta didik kelas VIII SMP Al Huda Jati Agung, pengambilan sampel menggunakan teknik Random Sampling didapat sampelnya yaitu kelas VIII B sebagai kelas eksperimen dan kelas VIII C sebagai kelas konvensional. Analisis data pada penelitian ini menggunakan uji manova. Menurut hasil analisis yaitu disimpulkan bahwa nilai dari Pillai's Trace, Wilks' Lambda, Hotelling's Trace dan Roy's Largest Root yaitu 0,009 dan nilai $\alpha$ kriteria uji yaitu 0,05 yang berarti nilai $p$ value lebih kecil dibandingkan nilai $\alpha$ kriteria uji, sehingga terdapat pengaruh model pembelajaran Example Non Example modifikasi metode tutor sebaya terhadap kemampuan penalaran dan koneksi matematis peserta didik. Model pembelajaran ini membuat suasana belajar menjadi lebih aktif dan peserta didik tidak malu bertanya jika kurang paham karena adanya tutor sebaya.
\end{abstract}

Kata kunci: Example Non Example, Tutor Sebaya, Penalaran Matematis, Koneksi Matematis.

\begin{abstract}
This study aims to determine the effect of the Example Non Example learning model modification of the peer tutor method on the mathematical reasoning abilities and mathematical connections of students in building material. This research is a type of Quasi Experimental Design research and its population is class VIII students of SMP Al Huda Jati Agung. Sampling using the Random Sampling technique obtained samples, namely class VIII B as the experimental class and class VIII C as the conventional class. Data analysis in this study used the Manova test. According to the results of the analysis, it is concluded that the value of Pillai's Trace, Wilks' Lambda, Hotelling's Trace and Roy's Largest Root is 0.009 and the a value of
\end{abstract}


the test criteria is 0,05, which means that the p-value is smaller than the $\alpha$ value of the test criteria, so that there is a model influence. Non Example Example learning modification of the peer tutor method of students' mathematical reasoning abilities and connections. This learning model makes the learning atmosphere more active and students are not ashamed to ask questions if they do not understand because of the presence of peer tutors.

Keywords: Example Non Example, Peer Tutor, Mathematical Reasoning, Mathematical Connection.

\section{PENDAHULUAN}

Pendidikan yaitu sebuah upaya dari pendidik guna membantu peserta didik dalam hal pengembangan potensi yang telah ada di dalam dirinya (Jauhari, 2020). Pendidikan merupakan sebuah proses yang bertujuan memberdayakan diri untuk melatih manusia di berbagai situasi. Beberapa aspek di dalam pendidikan yang dipertimbangkan yaitu pencerahan, penyadaran, perubahan prilaku dan pemberdayaan. Banyak teori serta konsep pendidikan yang mendiskusikan hal yang efektif untuk membuat manusia supaya tercerahkan, tersadarkan, terberdayakan serta menjadikan manusia sebagaimana manusia (Nurani, 2010).

Beberapa kemampuan yang melekat dalam matematika adalah pemecahan masalah matematis, komunikasi matemtis, dan menghubungkan kemampuan antara konsep-konsep matematika, serta penalaran dan koneksi matematis juga merupakan kemampuan yang melekat pada matematika. Tidak hanya itu, salah satu faktor yang berpengaruh pada berhasil atau tidaknya pencapaian kompetensi di suatu mata pelajaran yaitu cara pendidik dalam melaksanakan sebuah pembelajaran itu sendiri. Peserta didik masih berpusat pada peserta didik karena pembelajaran sekarang masih menggunakan metode ceramah dan maka dari itu peserta didik kurang dalam berpartisipasi pada proses belajar dan itu mengakibatkan tingkat penguasaan matematika peserta didik masih rendah.

Berdasarkan hasil wawancara yang telah dilakukan peneliti, diperoleh bahwa peserta didik lebih memahami soal matematika jika menggunakan contoh gambar atau media lainnya untuk menunjang penalaran dan koneksi matematis peserta didik. Selain itu, peserta didik juga masih malu bertanya kepada pendidik dan mengakibatkan proses pembelajaran tersebut menjadi tidak maksimal. Salah satu materi yang sulit pada pembelajaran matematika bagi peserta didik adalah materi Bangun Ruang. Untuk menunjang lagi kebenaran ada tidaknya masalah dalam hasil pembelajaran materi bangun ruang, peneliti memberikan soal kepada beberapa peserta didik berkaitan dengan materi bangun ruang dan di dapat hasil yaitu tingkat pemahaman peserta didik pada materi bangun ruang masih rendah sehingga menyebabkan kesalahan saat menyelesaikan soal yang diberikan. Peserta didik lebih mampu menjawab soal dengan pemakaian gambar. Pendidik pada sekolah itu berkata bahwa pembelajaran selama ini masih menerapkan belajar dengan cara konvensional dan proses pembelajaran tersebut masih monoton sehingga menyebabkan peserta didik mengalami kesulitan dalam memahami soal yang telah diberikan.

Beberapa penelitian yang relavan menunjukkan hasil bahwa model pembelajaran Example Non Example ini berpengaruh terhadap hasil pembelajaran 
peserta didik dan desain penelitiannya adalah Quasi Eksperiment (Siti, Salati, 2017). Penerapan dari pembelajaran kooperatif tipe example non example berpengaruh dan meningkatkan hasil belajar kognitif peserta didik (Ferdinant, Fenni, 2019). Peningkatan kemampuan pemahaman matematis peserta didik melalui model example non- example yang berbantuan dengan LKS berbasis ceria ini mendapatkan hasil bahwa dapat meningkatkan serta efektif untuk kemampuan pemahaman matematis peserta didik jenjang SMP (Siti, Safuri, Ramlah, 2018). Jadi, kesimpulan yang didapat dari hasil penelitian relevan adalah model pembelajaran Example Non Example dapat berpengaruh terhadap hasil pembelajaran. Peneliti akan memodifikasikan model pembelajaran Example Non Example dengan metode tutor sebaya. Model pembelajaran Example Non Example modifikasi Metode Tutor Sebaya ini akan digunakan pada mata pelajaran matematika terutama dalam materi bangun ruang karena tidak semua materi matematika dapat menggunakan model pembelajaran ini, serta peneliti akan melihat pengaruh model pembelajaran Example Non Example modifikasi Metode Tutor Sebaya terhadap kemampuan penalaran matematis dan koneksi matematis peserta didik.

\section{KAJIAN TEORI}

\section{A. Model Pembelajaran Example Non Example}

Model pembelajaran Example Non Example merupakan pembelajaran kooperatif yaitu pembelajaran kelompok yang terdiri dari beberapa peserta didik dalam sebuah kelompok. Pada model pembelajaran example non example ini memakai alat atau media berbentuk gambar yang digunakan oleh pendidik untuk menyampaikan pelajaran yang akan dijelaskan (Ahen, Syafdi, Astuty, 2019).

Pendidik mempergunakan gambar yang ditampilkan melalui gambar atau proyektor yang sudah di cetak oleh pendidik, bisa juga berupa poster. Media tersebut akan dijadikan pendidik sebagai perantara untuk menyampaikan materi yang akan disampaikan oleh pendidik (Nani, 2017). Dalam hal ini, pendidik diharuskan mampu membuat media gambar tersebut terjangkau bagi yang duduk di belakang, maka dari itu proses pembelajaran dijadikan kelompok-kelompok agar lebih efisien dan efektif. Dibentuknya kelompok pada model pembelajaran ini akan memberikan pengalaman kepada peserta didik untuk dapat bekerjasama dalam menganalisis gambar, dan memanfaatkan kelebihan-kelebihan yang dimiliki anggota kelompok sendiri dan saling menutupi kekurangannya.

Terdapat enam langkah-langkah dalm menggunakan model pembelajaran Example Non Example yaitu :

1) Contoh-contoh gambar disiapkan oleh pendidik dan yang sesuai dengan materi yang dijelaskan.

2) Gambar yang sudah disiapkan pendidik, ditempelkan pada papan tulis, atau juga bisa menggunakan proyektor dan juga pendidik bisa meminta bantuan kepada peserta didik untuk membawa gambar dan menunjukan kepada semua teman sekelasnya agar peserta didik yang duduk dibelakang dapat melihat gambar tersebut. Membuat kelompok juga bisa dilakukan pendidik pada tahap iniagar suasana belajar lebih efektif dan juga efisien.

3) Tahap selanjutnya, pendidik dapat mengarahkan serta memberikan kesempatan untuk peserta didik melakukan analisis pada gambar. 
4) Peserta didik dituntut agar dapat menuliskan hasil analisis yang telah diamatinya pada sebuah kertas.

5) Pendidik mempersilahkan kepada perwakilan kelompok untuk mempresentasikan hasil dari analisi yang telah dilakukan ke depan kelas. Pemaparan disini juga dapat melatih peserta didik agar dapat menjelaskan hasil yang sudah didapatkan.

6) Setelah pemaparan hasil analisis dari masing-masing kelompok, pendidik akan menerangkan terkait tujuan dan materi pembelajaran.

\section{B. Metode Tutor Sebaya}

Metode tutor sebaya merupakan sebuah metode dimana pendidik akan dibantu oleh peserta didik yang mempunyai kemampuan daya serap tinggi dalam pembelajaran dan berkompetensi serta dapat menjelaskan ulang kepada teman sebayanya yang belum memahami materi yang pendidik telah sampaikan (Hermansyah, Irianto, Fitria, 2020). Seorang tutor hendaknya memiliki kriteria:

1) Peserta didik dapat menerima dan menyetujui tutor agar peserta didik tidak lagi mempunyai rasa takut untuk bertanya kepada temannya tersebut.

2) Tutor harus dapat menjelaskan dan menjelaskan bahan atau soal yang telah diberikan kepada peserta didik.

3) Tidak kejam ataupun keras hati terhadap teman sebayanya.

Untuk memilih calon tutor dengan kemampuan penguasaan materi bangun ruang yang tinggi, peneliti akan memberikan test berupa soal agar hasil test tersebut tersebut digunakan untuk tolak ukur kemampuan penguasaan materi bangun ruang. Hasil test tersebut juga akan digunakan oleh pendidik untuk melihat kemampuan dari peserta didik yang beragam. Untuk peserta didik yang menyelesaikannya dengan nilai tertinggi, akan menjadi tutor untuk teman sebayanya. Selain itu juga pembentukan kelompok akan dilihat dari hasil test tersebut yaitu kemampuan yang rendah, sedang dan tinggi akan di campur dan di bentuk beberapa kelompok. Jadi, di dalam satu kelompok akan terdapat tutor, peserta didik berkemampuan rendah, sedang dan tinggi.

\section{Penalaran Matematis}

Penalaran matematis ialah kemampuan berpikir peserta didik untuk menarik suatu kesimpulan dari peryataan-pernyataan terkait objek matematika (Adam, Ismail, Evi, 2020). Berdasarkan aturan Dirjen Dikdasmen Depsiknas nomor 506/C/Kep/PP/2004 tentang indikator-indikator penalaran matematis antara lain:

1) Kemampuan menyajikan pernyataan matematika secara lisan, tertulis, ataupun gambar.

2) Kemampuan mengajukan dugaan.

3) Melakukan manipulasi matematika.

4) Menarik kesimpulan, menyusun bukti, memberikan alasan atau bukti terhadap kebenaran solusi.

5) Menarik kesimpulan dari pernyataan.

6) Memeriksa kesahihan suatu argumen.

7) Menemukan pola atau sifat dari gejala matematis untuk membuat generalisasi. 
Berdasarkan indikator kemampuan penalaran matematis tersebut, peneliti hanya menggunakan empat indikator diantaranya adalah :

1) Menarik kesimpulan, menyusun bukti, memberikan alasan atau bukti terhadap kebenaran solusi.

2) Kemampuan menyajikan pernyataan matematika secara lisan, tertulis, ataupun gambar.

3) Kemampuan mengajukan dugaan.

4) Kemampuan menarik kesimpulan dari pernyataan.

\section{Koneksi Matematis}

Koneksi matematis adalah kemampuan mengaitkan matematika pada bidang ilmu lain maupun dengan konsep matematika di kehidupan sehari-hari (Ikin, Padillah, 2019). Adapun tujuan koneksi matematis disekolah yaitu memperluas wawasan pengetahuan peserta didik. Peserta didik akan mampu menjangkau banyak aspek masalah baik itu di dalam maupun di luar sekolah dengan kemampuan koneksi matematis. Pengetahuan yang diperoleh peserta didik tersebut akan bertambah luas jika peserta didik mempunyai kemampuan koneksi matematis dan hal tersebut menjadikan peserta didik memperoleh banyak pengetahuan karena tidak tertumpu pada satu pokok bahsan yang sedang dibahas saja. Selain itu peserta didik juga akan memandang matematika yang tidak berdiri sendiri namun materi yang menjadi suatu keseluruhan yang padu. Indikator koneksi matematis menurut Sumarmo sebagai berikut:

1) Mencari hubungan berbagai representasi konsep dan prosedur;

2) Memahami hubungan antar topik matematika;

3) Menerapkan matematika dalam bidang lain atau dalam kehidupan seharihari;

4) Memahami representasi ekuivalen suatu konsep;

5) Mencari hubungan satu prosedur dengan prosedur lain dan representasi yang ekuivalen;

6) Menerapkan hubungan antar topik matematika dan antara topik matematika dengan topik yang lain.

Dari beberapa indikator diatas, peneliti menggunakan dua indikator yaitu :

1) Mempergunakan koneksi antar topik matematika dengan topik-topik lain.

2) Mempergunakan matematika pada kehidupan nyata atau juga pada bidang studi lain.

\section{METODE}

Pada Penelitian ini digunakannya pendekatan kuantitatif yang merupakan salah satu cara untuk pencarian ilmiah. Peneliti akan menggunakan jenis penelitian yaitu quasi eksperimental design atau bisa disebut dengan ekperimen semu yang mempunyai kelompok kontrol namun tidak digunakan untuk mengontrol variabel luar yang berpengaruh dengan terlaksananya eksperimen (Sugiyono, 2016). Pada metode ini digunakan dua kelas untuk penelitian yaitu kelas eksperimen dan kelas kontrol. Populasi pada penelitian ini adalah seluruh peserta didik kelas VIII SMP Al Huda Jati Agung. Penelitian dilakukan pada sekolah ini karena sesuai hasil pra-penelitian dengan memberikan tes berupa soal bangun ruang serta wawancara yang dilakukan peneliti pada pendidik. Hasil dari pra-penelitian tersebut yaitu menunjukkan bahwa tingkat pemahaman peserta didik pada materi bangun ruang masih rendah sehingga menyebabkan kesalahan 
saat menyelesaikan soal yang diberikan. Peserta didik lebih mampu menjawab soal dengan pemakaian gambar. Pendidik pada sekolah itu berkata bahwa pembelajaran selama ini masih menerapkan belajar dengan cara konvensional dan proses pembelajaran tersebut masih monoton sehingga menyebabkan peserta didik mengalami kesulitan dalam memahami soal yang telah diberikan. Sampel yang dipakai adalah random sampling atau kelas acak yang mana kelas yang satu akan diterapkan pembelajaran dengan menggunakan model pembelajaran example non example yang telah dimodifikasikan dengan metode tutor sebaya, sedangkan kelas kedua yaitu diterapkan pembelajaran seperti biasa pendidik mengajar dengan cara konvensional.

Instrument penelitian ini yaitu jenis test dimana test ini untuk mengetahui ada tidaknya perbedaan pengaruh model pembelajaran example non example modifikasi metode tutor sebaya dan pembelajaran metode ceramah terhadap kemampuan penalaran matematis dan kemampuan koneksi matematis peserta didik pada materi bangun ruang. Indikator penalaran matematis yaitu memeriksa keshahihan suatu argument, menyajikan pernyataan matematika secara tertulis, menarik kesimpulan dari suatu pernyataan dan mengajukan dugaan (Retno, 2016). Indikator koneksi matematis yaitu menemukan hubungan dari berbagai representasi tentang konsep dan prosedur matematika, menemukan hubungan antara prosedur satu dengan yang lainnya yang ekuivalen, menggunakan koneksi antara matematika dengan matematika sendiri maupun dengan ilmu yang lainnya dan mempergunakan matematika pada kehidupan nyata atau juga pada bidang studi lain (Nurfaidah, Elly, 2017).

Pada instrument penelitian dilakukan uji validitas dan uji reliabilitas berbantuan SPSS 23.0 setelah itu dilanjutkan dengan uji tingkat kesukaran dan uji daya beda. Dari keempat uji tersebut didapatkan hasil yaitu valid serta reliable sehingga instrument penelitian layak digunakan dalam penelitian. Terdapat teknik analisis data yang terdiri dari uji prasyarat dan uji hipotesis. Pada uji prasyarat ada uji normalitas yang menggunakan uji smirnov pada SPSS 23.0 dan adapun uji homogenitas yang menggunakan uji homogeneity of variances pada SPSS 23.0. Pada uji hipotesis akan menggunakan uji manova. Uji manova dibantu dengan menggunakan program aplikasi SPSS 23.0.

\section{HASIL DAN PEMBAHASAN}

Sebelum memulai pembelajaran menggunakan model pembelajaran Example Non Example, peserta didik diberikan beberapa soal terlebih dahulu untuk menentukan tutor sebaya serta anggota kelompok masing-masing. Seteah itu, dilakukannya pembelajaran menggunakan model pembelajaran Example Non Example modifikasi metode tutor sebaya. Lalu diberikan posttest menggunakan soal yang sudah di uji kelayakannya. Dari hasil posttest didapat data amatan penalaran matematis dan koneksi matematis dengan bantuan program aplikasi SPSS 23.0 yang dapat dilihat pada tabel berikut ini :

Tabel 1. Data Amatan Kemampuan Penalaran Matematis

\begin{tabular}{l|l|r|r}
\hline \multicolumn{2}{l|}{} & eksperimen & \multicolumn{2}{|c}{ kontrol } \\
\hline $\mathrm{N}$ & Valid & 21 & 22 \\
\cline { 2 - 4 } & Missing & 1 & 0 \\
\hline
\end{tabular}




\begin{tabular}{l|r|r} 
Mean & 79,95 & 67,41 \\
\hline Median & 81,00 & 69,00 \\
\hline Mode & 88 & 56 \\
\hline Std. Deviation & 13,658 & 12,378 \\
\hline Variance & 186,548 & 153,206 \\
\hline Range & 56 & 50 \\
\hline Minimum & 44 & 38 \\
\hline Maximum & 100 & 88 \\
\hline Sum & 1679 & 1483 \\
\hline
\end{tabular}

Pada Tabel 1 dapat disimpulkan bahwa kemampuan penalaran matematis peserta didik pada kelas eksperimen lebih baik dibandingkan pada kelas kontrol.

Tabel 2. Data Amatan Kemampuan Koneksi Matematis

\begin{tabular}{l|l|r|r}
\hline \multicolumn{2}{l|}{} & eksperimen & kontrol \\
\hline N & Valid & 21 & 22 \\
\cline { 2 - 4 } & Missing & 1 & 0 \\
\hline Mean & 65,33 & 53,82 \\
\hline Median & 63,00 & 53,00 \\
\hline Mode & $56^{\mathrm{a}}$ & $50^{\mathrm{a}}$ \\
\hline Std. Deviation & 14,664 & 13,609 \\
\hline Variance & 215,033 & 185,203 \\
\hline Range & 50 & 50 \\
\hline Minimum & 44 & 31 \\
\hline Maximum & 94 & 81 \\
\hline Sum & 1372 & 1184 \\
\hline
\end{tabular}

Pada Tabel 2 dapat disimpulkan bahwa kemampuan koneksi matematis peserta didik pada kelas eksperimen lebih baik dibandingkan pada kelas kontrol.

Berdasarkan data amatan yang telah dijelaskan maka didapatkan kesimpulan yaitu dengan menggunakan model pembelajaran Example Non Example modifikasi metode tutor sebaya lebih baik dibandingkan dengan pembelajaran konvensional yaitu metode ceramah dan model tersebut dapat digunakan untuk meningkatkan kemampuan penalaran matematis dan koneksi matematis peserta didik.

\section{Uji Normalitas}

Analisis uji normalitas dengan berbantuan aplikasi SPSS 23.0 dapat dilihat pada tabel berikut :

Tabel 3. Hasil Uji Normalitas Kemampuan Penalaran dan Koneksi Matematis

\begin{tabular}{|c|c|c|c|c|c|c|c|}
\hline & \multirow{2}{*}{ Kelas } & \multicolumn{3}{|c|}{$\begin{array}{l}\text { Kolmogorov- } \\
\text { Smirnov }^{\mathrm{a}}\end{array}$} & \multicolumn{3}{|c|}{ Shapiro-Wilk } \\
\hline & & Statistic & df & Sig. & Statistic & df & Sig. \\
\hline
\end{tabular}




\begin{tabular}{l|l|l|l|l|l|l|l}
$\begin{array}{l}\text { Penalaran } \\
\text { Matematis }\end{array}$ & Eksperimen & 0,151 & 21 & $0,200^{*}$ & 0,944 & 21 & 0,262 \\
\cline { 2 - 7 } & Kontrol & 0,140 & 22 & $0,200^{*}$ & 0,943 & 22 & 0,231 \\
\hline $\begin{array}{l}\text { Koneksi } \\
\text { Matematis }\end{array}$ & Eksperimen & 0,119 & 21 & $0,200^{*}$ & 0,952 & 21 & 0,376 \\
& Kontrol & 0,114 & 22 & $0,200^{*}$ & 0,972 & 22 & 0,764 \\
\hline
\end{tabular}

Berdasarkan tabel di atas dapat dilihat bahwa hasil perhitungan uji normalitas penalaran matematis dan koneksi matematis dilihat dari KolmogrovSmirnov dengan melihat nilai Sig pada kelas eksperimen dan kontrol yaitu 0,200 lebih besar dari nilai $\alpha=0,05$ maka $\mathrm{H}_{0}$ diterima. Dengan demikian menunjukkan bahwa kelas eksperimen dan kelas kontrol pada kemampuan penalaran matematis dan koneksi matematis pada penelitian ini berasal dari populasi yang berdistribusi normal.

\section{Uji Homogenitas}

Analisis uji homogenitas dengan berbantuan aplikasi SPSS 23.0 dapat dilihat pada tabel berikut :

Tabel 4. Hasil Uji Homogenitas Kemampuan Penalaran dan Koneksi Matematis

\begin{tabular}{l|l|r|r|r|r}
\hline \multicolumn{2}{c|}{} & $\begin{array}{c}\text { Levene } \\
\text { Statistic }\end{array}$ & df1 & df2 & \multirow{2}{*}{ Sig. } \\
\hline $\begin{array}{l}\text { Penalaran } \\
\text { Matematis }\end{array}$ & Based on Mean & 0,052 & 1 & 41 & 0,820 \\
\cline { 2 - 6 } & Based on Median & 0,047 & 1 & 41 & 0,829 \\
\cline { 2 - 6 } & Based on Median and with adjusted df & 0,047 & 1 & 39,919 & 0,829 \\
\cline { 2 - 6 } & Based on trimmed mean & 0,036 & 1 & 41 & 0,851 \\
\hline $\begin{array}{l}\text { Koneksi } \\
\text { Matematis }\end{array}$ & Based on Mean & 0,081 & 1 & 41 & 0,778 \\
\cline { 2 - 6 } & Based on Median & 0,053 & 1 & 41 & 0,819 \\
\cline { 2 - 6 } & Based on Median and with adjusted df & 0,053 & 1 & 40,042 & 0,819 \\
\cline { 2 - 6 } & Based on trimmed mean & 0,076 & 1 & 41 & 0,784 \\
\hline
\end{tabular}

Dari tabel di atas didapatkan hasil yaitu Sig. pada penalaran matematis yaitu 0,820 dengan Sig. $>\alpha$, maka $\mathrm{H}_{0}$ diterima dan Sig. pada kemampuan koneksi matematis yaitu 0,778 dengan Sig. $>\alpha$, maka $\mathrm{H}_{0}$ diterima. Dapat disimpulkan bahwa variansi pada setiap kelompok sama atau homogen baik itu kemampuan penalaran matematis maupun kemampuan koneksi matematis.

\section{Uji Hipotesis}

Setelah diketahui data berdistribusi normal yang berasal dari populasi homogen maka selanjutnya yaitu uji hipotesis menggunakan uji manova. Uji tersebut bertujuan untuk mengetahui apakah terdapat pengaruh model pembelajaran Example Non Example modifikasi metode tutor sebaya terhadap kemampuan penalaran matematis dan koneksi matematis peserta didik. 
Tabel 5. Uji Hipotesis 1 dan 2

\begin{tabular}{l|c|c|c|c|c|c}
\hline \multirow{2}{*}{ Source } & $\begin{array}{c}\text { Dependent } \\
\text { Variable }\end{array}$ & $\begin{array}{c}\text { Type III } \\
\text { Sum of } \\
\text { Squares }\end{array}$ & df & $\begin{array}{c}\text { Mean } \\
\text { Square }\end{array}$ & F & Sig. \\
\hline \multirow{3}{*}{ EnE } & $\begin{array}{c}\text { Penalaran } \\
\text { Matematis }\end{array}$ & 1690,427 & 1 & 1690,427 & 9,975 & 0,003 \\
\cline { 2 - 7 } & $\begin{array}{c}\text { Koneksi } \\
\text { Matematis }\end{array}$ & 1424,665 & 1 & 1424,665 & 7,132 & 0,011 \\
\hline
\end{tabular}

Berdasarkan tabel berikut, dapat disimpulkan bahwa nilai $p$-value pada kemampuan penalaran matematis adalah 0,003 dan nilai $\alpha=0,05$ yang berarti nilai $p$-value lebih kecil dari nilai $\alpha$ kriteria uji, sehingga $H_{0 A}$ ditolak. Dapat disimpulkan bahwa terdapat perbedaan antara peserta didik yang diberi perlakuan model pembelajaran Example Non Example modifikasi metode tutor sebaya dengan peserta didik yang menggunakan metode konvensional terhadap kemampuan penalaran matematis peserta didik. Nilai $p$-value pada kemampuan koneksi matematis adalah 0,011 dan nilai $\alpha=0,05$ yang berarti nilai $p$-value lebih kecil dari nilai $\alpha$ kriteria uji, sehingga $H_{0 B}$ ditolak. Dapat disimpulkan bahwa terdapat perbedaan antara peserta didik yang diberi perlakuan model pembelajaran Example Non Example modifikasi metode tutor sebaya dengan peserta didik yang menggunakan metode konvensional terhadap kemampuan koneksi matematis peserta didik. Selanjutnya yaitu uji multivarian dan didapat hasil pada tabel berikut :

Tabel 6. Uji Hipotesis 3

\begin{tabular}{lcccrrr}
\hline \multirow{2}{*}{ Effect } & Value & F & Hypothesis df & Error df & Sig. \\
\hline \multirow{3}{*}{ EnE } & Pillai's Trace & 0,209 & $5,276^{\mathrm{b}}$ & 2,000 & 40,000 & 0,009 \\
\cline { 2 - 7 } & Wilks' Lambda & 0,791 & $5,276^{\mathrm{b}}$ & 2,000 & 40,000 & 0,009 \\
\cline { 2 - 7 } & Hotelling's Trace & 0,264 & $5,276^{\mathrm{b}}$ & 2,000 & 40,000 & 0,009 \\
\cline { 2 - 7 } & Roy's Largest Root & 0,264 & $5,276^{\mathrm{b}}$ & 2,000 & 40,000 & 0,009 \\
\hline
\end{tabular}

Berdasarkan tabel di atas dapat disimpulkan bahwa nilai dari Pillai's Trace, Wilks' Lambda, Hotelling's Trace dan Roy's Largest Root yaitu 0,009 dan nilai $\alpha$ kriteria uji yaitu 0,05 yang berarti nilai $p$-value lebih kecil dibandingkan nilai $\alpha$ kriteria uji, sehingga $H_{0 A B}$ ditolak. Dapat disimpulkan bahwa terdapat perbedaan antara peserta didik yang diberi perlakuan model pembelajaran Example Non Example modifikasi metode tutor sebaya dengan peserta didik yang menggunakan metode konvensional terhadap kemampuan penlaran matematis dan koneksi matematis peserta didik.

Hasil dari penelitian yaitu dapat disimpulkan bahwa pembelajaran dengan menerapkan model pembelajaran Example Non Example modifikasi metode tutor sebaya berhasil meningkatkan kemampuan penalaran matematis dan koneksi matematis peserta didik. Hal itu karena pada kelas eksperimen yang menerapkan model pembelajaran Example Non Example modifikasi metode tutor sebaya, peserta didik melihat gambar dan contoh-contohnya pada materi bangun ruang sehingga lebih mudah dipahami. Peserta didik juga melakukan diskusi untuk 
dapat bertukar pikiran dengan teman kelompoknya. Selain itu, bagi peserta didik yang kurang memahami materi dapat bertanya kepada tutor sebayanya dan hal tersebut membuat peserta didik tidak malu lagi jika ingin bertanya karena peserta didik dapat bertanya ke tutor yang ada pada kelompok masing-masing.

Kegiatan dalam proses pembelajaran membuat peserta didik berperan aktif selama proses pembelajaran. Pembelajaran akan terasa menyenangkan bagi peserta didik jika pendidik berani bereksperimen dalam mengembangkan suasana proses pembelajaran. Dengan menggunakan model pembelajaran Example Non Example dapat membantu peserta didik memahami konsep belajar dan membuat peserta didik antusias belajar hal-hal baru, dan hal tersebut akan memancing motivasi belajar peserta didik kedepannya (Ginanjar, Ryky, 2018). Pada penelitian ini, model pembelajaran Example Non Example dimodifikasikan dengan metode tutor sebaya. Metode tutor sebaya merupakan sebuah metode dimana pendidik akan dibantu oleh peserta didik yang mempunyai kemampuan daya serap tinggi dalam pembelajaran dan berkompetensi serta dapat menjelaskan ulang kepada teman sebayanya yang belum memahami materi yang pendidik telah sampaikan (Hermansyah, Irianto, Fitria, 2020). Oleh karena itu, pembelajaran Example Non Example modifikasi metode tutor sebaya mampu meningkatkan kemampuan penalaran dan koneksi matematis peserta didik.

\section{SIMPULAN DAN SARAN}

Hasil penelitian dapat dijawab dari rumusan masalah yang telah dilakukan mengenai pengaruh model pembelajaran example non example modifikasi metode tutor sebaya terhadap kemampuan penalaran dan koneksi matematis peserta didik yang dapat disimpulkan dalam beberapa hal. Pertama, hasil analisis kemampuan penalaran matematis peserta didik yaitu di dapat nilai $p$-value pada kemampuan penalaran matematis adalah 0,003 dan nilai $\alpha=0,05$ yang berarti nilai $p$-value lebih kecil dari nilai $\alpha$ kriteria uji, sehingga $H_{0 A}$ ditolak. Maka dari itu disimpulkan bahwa terdapat perbedaan antara model pembelajaran Example Non Example modifikasi metode tutor sebaya dengan pembelajaran metode ceramah terhadap kemampuan penalaran matematis peserta didik. Kedua, hasil analisis kemampuan koneksi matematis peserta didik yaitu di dapat nilai p-value pada kemampuan koneksi matematis adalah 0,011 dan nilai $\alpha=0,05$ yang berarti nilai $p$-value lebih kecil dari nilai $\alpha$ kriteria uji, sehingga $H_{0 B}$ ditolak. Maka dari itu disimpulkan bahwa terdapat perbedaan antara model pembelajaran Example Non Example modifikasi metode tutor sebaya dengan pembelajaran metode ceramah terhadap kemampuan koneksi matematis peserta didik. Ketiga, hasil analisis kemampuan penalaran matematis dan koneksi matematis peserta didik yaitu di dapat nilai dari Pillai's Trace, Wilks' Lambda, Hotelling's Trace dan Roy's Largest Root yaitu 0,009 dan nilai $\alpha$ kriteria uji yaitu 0,05 yang berarti nilai $p$-value lebih kecil dibandingkan nilai $\alpha$ kriteria uji, sehingga $H_{0 A B}$ ditolak. Maka dapat disimpulkan bahwa terdapat perbedaan antara model pembelajaran Example Non Example modifikasi metode tutor sebaya dengan pembelajaran metode ceramah terhadap kemampuan penalaran matematis dan koneksi matematis peserta didik.

Pendidik diharapkan selalu membuat suasana dalam kelas menjadi aktif dan juga membuat pembelajaran matematika menyenangkan contohnya dengan menggunakan model pembelajaran Example Non Example modifikasi metode tutor sebaya ini agar tercapainya tujuan pembelajaran. Bagi peneliti selanjutnya 
yang ingin menggunakan model pembelajaran Example Non Example diharapkan dapat melihat kemampuan matematis pada pokok bahasan lainnya dan lebih kreatif serta inovatif dalam menerapkan model pembelajaran Example Non Example sehingga peneliti selanjutnya tidak terpaku pada penelitian yang sudah dilakukan. Kritik serta saran sangat dibutuhkan oleh peneliti agar penelitian selanjutnya dapat menjadi lebih baik lagi.

\section{DAFTAR PUSTAKA}

Aisah, S., and Asmahasanah, S. (2017). Pengaruh model Cooperative Learning Tipe Example Non Example terhadap Hasil Belajar Siswa pada Materi Pelajaran IPA. Attadib Journal of Elementary Education. 1(2).

Aji, W., G., and Sary, M., S. (2018). Keefektifan Model Example Non-Example Berbantu Media VISETA Terhadap Hasil Belajar Siswa Kelas V Sekolah Dasar. MALIH PEDDAS: Majalah Ilmiah Pendidikan Dasar, 8(1).

Alexander, F., and Pono, F. (2019). Penerapan Metode Pembelajaran Kooperatif Tipe Example Non Example untuk Meningkatkan Hasil Belajar Kognitif Siswa. Jurnal Ilmiah Religiosity Entity Humanity (JIREH), 1(2).

Hermansyah, Aras, I., and Harum, F. (2020). Efektivitas Metode Tutor Sebaya dalam Meningkatkan Kemampuan Number Sense Siswa Kelas VII SMP Negeri 1 Duripoku. MUST : Journal of Mathematics Education, Science and Technology,5(1).

Hestavia, A., Maizora, S., and Yensy, A. (2019). Perbandingan Hasil Belajar Antara Model Pembelajaran Example Non Example dengan Pembelajaran Saintifik. Jurnal Penelitian Pembelajaran Matematika Sekolah, 3(1).

Jauhari, I. (2020). Konsep Pendidikan Ibnu Khaldun dan Relevansinya terhadap Pendidikan di Era Modern, Jurnal Komunikasi dan Pendidikan Islam, 9(1).

Marsitin, R. (2016). Kemampuan Penalaran dan Koneksi Matematis dalam Pembelajaran Matematika dengan Problem Solving. JPM : Jurnal Pendidikan Matematika, 2(1).

Mediatati, N. (2017). Meningkatkan Hasil Belajar PPKN Menggunakan Model Pembelajaran Example Non Example Pada Siswa Kelas VIIIE SMP Negeri 6 Salatiga. Journal of Education Research and Evolution, 1(2).

Rohmah, S., and Musa, S. (2018). Peningkatan Kemampuan Pemahaman Matematis Siswa SMP melalui model Example Non Example berbantuan LKS Berbasis Ceria, Sesiomadika.

Sugandi, I., and Akbar, P. (2019). Efektivitas Penerapan Startegi React Terhadap Kemampuan Koneksi Matematis Dan Self Efficacy Siswa SMP. Journal Cendekia : Jurnal Pendidikan Matematika, 3(2).

Sugiyono, (016). Metode Penelitian Kuantitatif, Kualitatif dan R\&D. Bandung: Alfabeta.

Tasni, N., and Susanti, E. (2017). Membangun Koneksi Matematis Siswa Dalam Pemecahan Masalah Verbal, Jurnal Tadris Matematika, 10(1).

Yunus, A., Djakaria, I., and Hulukati, A. (2020). Pengaruh Pendekatan Kontekstual terhadap Kemampuan Penalaran Matematis Ditinjau dari Gaya Kognitif Peserta Didik. Jambura Journal Of Mathematics, 2(1). 